OPEN ACCESS

Edited by:

Matt Henn,

Nottingham Trent University,

United Kingdom

Reviewed by:

Helga Kristin Hallgrimsdottir,

University of Victoria, Canada

Mireille Lalancette,

Université du Québec à

Trois-Rivières, Canada

Cesar Guzman-Concha,

Université de Genève, Switzerland

*Correspondence:

Francis Dupuis-Déri

dupuis-deri.francis@uqam.ca

Specialty section:

This article was submitted to

Political Participation,

a section of the journal

Frontiers in Political Science

Received: 28 November 2020

Accepted: 29 March 2021

Published: 27 April 2021

Citation:

Dupuis-Déri F (2021) Youth Strike for

Climate: Resistance of School

Administrations, Conflicts Among

Students, and Legitimacy of

Autonomous Civil Disobedience-The

Case of Québec.

Front. Polit. Sci. 3:634538.

doi: 10.3389/fpos.2021.634538

\section{Youth Strike for Climate: Resistance of School Administrations, Conflicts Among Students, and Legitimacy of Autonomous Civil Disobedience-The Case of Québec}

\author{
Francis Dupuis-Déri ${ }^{1,2 *}$ \\ ${ }^{1}$ Department of political science, Université du Québec à Montréal, Montreal, QC, Canada, ${ }^{2}$ Collectif de Recherche Action \\ Politique et Démocratie (CAPED), Montreal, QC, Canada
}

This text presents the results of the first research conducted on "green" actions and strikes for climate in high schools across Québec, a Canadian province that witnessed in 2019 the larger street protests of the international youth movement. Based on 20 semistructured interviews with students from 12 high schools, letters from school principals addressed to parents, and research in the media, this text reaffirms that schools are a place of political conflicts and struggles not only between students and adults but also between students in opposite currents of the movement. It is also a reminder of the involvement of young people in autonomous direct action groups (Extinction Rebellion). The discussion then focuses on potential implications of the movement for future elections, the legitimacy of these collective actions in relation to the philosophical debate about civil disobedience (John Rawls, Ronald Dworkin, Manuel Cerveza-Marzal, and Alan Carter), and the hope for a renewal of the student movement in Québec in the face of a disaster of unprecedented scale.

Keywords: youth strike for climate, youth politics, climate change, school, ecologism, civil disobedience, Québec, social movements

\section{INTRODUCTION}

In August 2018, Greta Thunberg-a "Swedish 15-year-old who's cutting class to fight the climate crisis" (The Guardian, September 1st, 2018) - started to stand every Friday afternoon in front of the Riksdad, the national parliament, and then launched a world movement known as Skolstrejk för klimatet, or "school strike for climate." In Montréal, a 17-year-old Secondary five student, Sara Montpetit, responded to the call from Sweden by launching Pour un futur Montréal (For a Future Montréal) with other students. Already in April 2012, an Earth Day march in Montréal was described by the media as the largest protest in Canadian history, with the police estimating its size at 150,000 people and the organizing committee at 300,000 (La Presse, April 22nd, 2012). On March 15, 2019, the first global day of action for climate, the organizing committee for the protest in Montréal estimated the crowd at 150,000 people (Radio Canada, March 15, 2019). In September 2019, approximately one and a half million people marched for climate in about 150 countries (The Times, May 24, 2019; Washington Post, September 20, 2019). According to the media, the protest in Montréal was not only the largest in the country but also worldwide, with 300,000 participants 
based on police estimates and 500,000 according to the organizing committee, compared to 250,000 in New York and 100,000 in larger cities such as Berlin and London (New York Times, September 21, 2019; Journal de Montréal, September 27, 2019). Greta Thunberg herself marched on the streets of Montréal and spoke to the crowd, after addressing these words at the United Nations Climate Summit in New York:

\begin{abstract}
“This is all wrong. I shouldn't be up here. I should be back in school on the other side of the ocean.... How dare you? You have stolen my dreams and my childhood, with your empty words and yet I am one of the lucky ones. People are suffering. People are dying. Entire ecosystems are collapsing. We are in the beginning of a mass extinction and all you can talk about is money and fairy tales of eternal economic growth. How dare you? For more than 30 years, the science has been crystal clear. How dare you continue to look away?"
\end{abstract}

This exceptionally large-scale movement arises as thousands of scientists and international organizations such as the Intergovernmental Panel on Climate Change (IPCC) confirm that human activities pose a threat to the planet. In the province of Québec, new ecologist groups have emerged over the last few years, such as La Planète sinvite au parlement (The planet goes to parliament), a grassroots coalition aimed at influencing the government, the Coalition étudiante pour un virage environmental et social (Student coalition for a social and environmental shift) (CEVES), and local branches of Extinction Rebellion (XR), a self-organized network founded in Great Britain, which uses civil disobedience (Axon, 2019).

Many conservative and reactionary columnists in Québec published derogatory critiques of Greta Thunberg and the youth who responded to her call (see also Bergmann and Ossewaarde, 2020). In a Montréal-based newspaper Le Devoir, for example, Rioux (2019a) made ironic remarks about "Saint Greta," deploring the "irrational nature of this quasi-religious craze," even talking about a "dictatorship of the emotions" (Rioux, $2019 b)^{1}$. In the Journal de Montréal, several columnists ridiculed the movement, for example, Bock-Côté (2019a) in his missive, "Greta Thunberg, la prophétesse" (Greta Thunberg, Prophetess). $\mathrm{He}$ argued that, "the place for children and teenagers is not in the streets but at school. [...] The fight for climate shouldn't be transformed into a children's crusade. The conscription of youth, by definition impressionable and spontaneously fanatic, should concern us." In another column, he deplored that, "the ideological recruitment of youth is the stuff of totalitarian regimes [...] youth, easily impassioned, can easily be fanaticized" (Bock-Côté, 2019b).

Obviously, a more favorable posture toward this movement can be adopted. This article will resituate these Québec-based mobilizations within the little-known tradition of student strikes and the history of "green" actions in schools. This will allow institutional obstacles to be identified before examining divisions among strikers and then addressing the issue of legitimacy

\footnotetext{
${ }^{1}$ This columnist tends to see tyranny, totalitarianism, and witch-hunts everywhere (see his February 14 and April 232020 columns, and also Ancelovici, 2017 and Le Glaunec, 2020).
}

of radical civil disobedience. Our main argument is that political scientists and sociologists working on social movements should seriously consider political dynamics within schools to understand their influence on the choices of students to strike for climate. These choices may be analyzed through lenses of Do-itOurselves (DiO) politics and civil disobedience that is in relation to the issue of political autonomy and legitimacy.

\section{LITERATURE REVIEW AND THEORETICAL FRAMEWORK}

To my knowledge, this is the first comprehensive study aimed at developing an analysis of the Québec wing of the youth movement for climate (see also Dupuis-Déri, 2021a). Some preliminary findings can already be drawn about the relationship of students to the parliamentary electoral regime, political conflict, and activist experience. As Weiss (2020) summarizes, with regard to academic literature about youth political participation:

\begin{abstract}
"Representatives of the disengagement paradigm within the literature underpin their argument with empirical findings, such as young adults being the least likely to vote in national elections, the drop of youth membership in political parties, and generally low levels of political interest. On the other hand, the literature on an engagement paradigm of youth participation represents a more optimistic view as it is based on findings in the context of new forms of political participation, which are more appealing to and are used more frequently by young adults."
\end{abstract}

Yet, youth political participation may be simultaneouslyeven for one individual-(1) traditional, institutional, and collaborative (with the authority) and (2) innovative, extrainstitutional (autonomous), and contentious. Indeed, students involved in the youth climate movement resort to integration through election (delegate on student councils) or not (member of the green committee), collaboration (clean-up days), negotiation (lobbying and petitions), and direct actions $\mathrm{DiO}$ politics: boycott and buycott (clothes and food), strike, picket, sit-in, street protest, banner drop, and sabotage.

Moreover, climate strikers participating in our research (see section Material and methods) were quite excited about the prospect of voting in the next provincial elections (Shields, 2019). Such a stance should rejoice the vast majority of academics studying "democracy" in school and believing that the goal should not be for youth to become autonomous and enjoy sovereign power at school, but rather to be trained to vote at school, so that they develop this habit once they reach voting age. In other words, the goal is not to increase youth power and autonomy, but reduce adult electoral abstention (Milner, 2005; Pache-Hébert et al., 2014; Lacroix, 2016; Godbout, 2017; for a more critical perspective, see Westheimer and Kahne, 2004; Reginensi, 2005; Dupuis-Déri, 2006; Wall, 2011; Garneau, 2016; Caron, 2018). One of the strikers interviewed here stated that "Everyone at my school has worked out the voting age. [...] I am afraid that there isn't enough time left, that's why it's important to act now. I have hope for the next elections." Nevertheless, there 
is no way of knowing if these youth will vote once they reach adulthood, nor whether their vote will have an impact on party programs or the composition of parliament or government. A 15-year-old respondent commented with stunning clarity, "It's important to vote, but I know we grow and I don't know how I will see things at that time," when she reaches the age of majority.

It seems more interesting, politically speaking, to observe that this youth movement for climate confirms the hypothesis of Adams (1991) and other authors who see school as a political space, where students engage in important conflicts. These political struggles are not only vertical because they seek to put pressure on the government and political parties and on the school administration, but they are also horizontal because students for and against mobilization and camps defending different or even competing practices and perspectives are placed in opposition to each other.

Researcher, Sarah Pickard, explains that ecologist youth prefer "(DiO) politics" or feel they have no choice but to practice it. After Do-it-Yourself (DiY) from the punk movement, producing its own publications (zines) and music without the involvement of private companies (e.g., record labels), and Do-it-Together (DiT) from disabled activists, $\mathrm{DiO}$ politics "is when citizens [?] take initiatives and act politically without relying on traditional collective structures, such as political parties and trade unions, to inform, organize and mobilize in a top-down way" (Pickard, 2019 , p. 5). For present young ecologists, $\mathrm{DiO}$ politics are about individual lifestyle politics (veganism, recycling, boycotting, etc.) and autonomous, horizontal organization of collective direct actions bringing people together, channeling emotions such as frustration and anger, fostering joy and hope, and eventually functioning in a bottom-up fashion to put pressure on decisionmakers at the top of our political and economic institutions.

The DiO politics approach is all the more necessary and legitimate for these young, primary, and high school ecologists because student councils and green committees often lack real power and are kept under adult authority (as we shall see) (Westheimer and Kahne, 2004; Dupuis-Déri, 2006; Simon, 2020). Consequently, their $\mathrm{DiO}$ politics are expressed through protests, school strikes, and actions such as dieins, blockades, banner drops after scaling urban structures, and super-gluing hands onto shop windows, i.e., through civil disobedience.

Therefore, these ecologist direct actions at school and outside of school raise questions discussed in moral and political philosophy about civil disobedience actions. According to a more moderate approach, civil disobedience is only justified in liberal-republican regimes when it succeeds in rallying majority opinion and protests an unjust decision or law according to the fundamental rights of a country. In this regard, John Rawls described his approach as a "constitutional theory of civil disobedience" (Rawls, 1999, p. 319-343). Zinn (1968) decried the limits of such an approach, observing that civil disobedience can also be used to challenge global problems, such as poverty or war (and he could have included pollution), and not simply an isolated law. Together with Henry David Thoreau and other proponents of civil disobedience, he also argued that a single individual might be justified to oppose the will of the majority.
Nevertheless, Ronald Dworkin distinguished three types of civil disobedience, according to their grounds: (1) integritybased, corresponding to situations in which an individual feels compelled to disobey in order to preserve moral coherence, for example, by refusing to go to war; (2) justice-based, when it is a matter of defending minority rights or protesting an oppressive policy; and (3) policy-based, against a law or decision perceived as dangerous to the entire population. Dworkin also differentiated two strategies. The first, a persuasive strategy, "hopes to force the majority to listen to arguments against its program" (Dworkin, 1985, p. 109). From a deliberative approach, there is a hope that the civil disobedience and popular protest have positive effects by: (1) widening the agenda, (2) increasing participation, (3) representation, (4) disseminating new information and arguments, (5) stimulating imagination, (6) pushing decision-makers to act, and, potentially (7) opening a new round of deliberation (Dupuis-Déri, 2007). However, this deliberative approach seems overly optimistic in light of the obstinacy of political authorities in ignoring disobedience movements and the asymmetry of power relations in "pluralist" societies (Fuji Johnson, 2012). Dworkin consequently allows for a disruptive approach, a "non-persuasive strategy" that "aims not to change the majority's mind, but to increase the cost of pursuing the program the majority still favors" (Dworkin, 1985, p. 109). According to Dworkin, the former strategy (persuasive) is more legitimate because it is consistent with the majority rule, whereas the second strategy (disruptive) is less so because it imposes the will of a minority over the majority. To illustrate the second case, he discusses a very sensitive issue in the 1980s, namely the deployment of Euromissiles in Western Europe enabling a "limited nuclear war." The majority may have believed that these extremely dangerous and destructive weapons represented a good way of limiting the risk of war by discouraging the USSR from launching a traditional attack with the Red Army or atomic strikes. This was the (fundamentally irrational) logic of the "balance of terror" of the Cold War. The minority practicing civil disobedience, numbering in the millions in West Germany and elsewhere, could thus be considered as a significant threat to military and political ("better red than dead") stability in Europe. In such a context, more intense state repression can be anticipated (see also Arendt, 1972).

These philosophical discussions about the legitimacy of civil disobedience take for granted that the disobedient lives in a liberal-republican regime and enjoy the so-called freedom of press and association and free elections. Yet, according to the French philosopher Manuel Cervera-Marzal (2013, p. 13-14), "civil disobedience is at least legitimate, if not necessary, in a clearly undemocratic regime, where human rights and freedom are systematically violated" (see also Walzer, 1970). In this respect, it should be politically relevant to highlight that the youth in Québec can neither vote nor run for municipal, provincial, or federal elections, but also that parents and adults ruling the school system strictly limit and infringe their freedom of expression and association and maintain oversight of school committees, such as elected student councils. 


\section{MATERIALS AND METHODS}

The study focused on the under-studied experiences of youth from 12 to 17, who have yet to reach the age of majority but are politically active in school. In 2015, a study on "democracy and protest in high school" in Québec was initiated-well before Greta Thunberg was heard of-by designing a mixed research method. In Québec, there have been studies of youth political involvement examining specific cohorts; for example, the post-secondary student movement (including Surprenant and Bigaouette, 2013; Ancelovici and Dupuis-Déri, 2014; TheurillatCloutier, 2017; Ancelovici and Guzmán-Concha, 2019), or "youth" between 15 and 30 (Gauthier, 2003) or 18 and 30 (Gallant, 2018), or women between 18 and 30 years (Quéniart and Jacques, 2004).

A search through archives of periodicals at Bibliothèque et archives nationales du Québec (BAnQ) and Québec media websites allowed produced documentary sources pertaining to 250 school strikes across Québec history. About 20 semi-directed interviews were conducted with 12- to 17-year-old students and 55 interviews with adults, mostly between 18 and 25 years old and who shared teenage memories. Although the study did not specifically focus on the topic, a number of respondents had participated in Extinction Rebellion meetings and actions in Montréal and Sherbrooke. After the interviews, students forwarded copies of letters sent to students and parents by the school administration. This material serves as the basis of an initial analysis of climate mobilizations in 12 schools in Québec (three private and nine public). To respect anonymity, names of students or affiliated schools will not be cited, where this would allow for identification of respondents.

This is a preliminary research about the youth climate movement in Québec. In the future, there will doubtlessly be further examination of this mobilization: through other methodologies, questions, and reflections. Most importantly, students currently attending high school will certainly study their own movement. All of this work will contribute to gain a clearer understanding of the movement composition, its motivations, its political meaning, and its consequences.

\section{RESULTS: "GREEN" ACTIONS IN SCHOOLS}

In schools, young people who wish to get socially and politically involved can join the student council, an elected body, though in reality dominated by adults who sit on the board and prepare the agenda, determine speaking order, and decide what will be discussed. Moreover, the school administration reserves the right to veto decisions rendered by the council, as reported by several young people who volunteered their time with such councils. In essence, adults can reject the candidacy of students deemed problematic, irresponsible, or not very presentable, and even manipulate election results (studies of student councils and school democracy confirm this fact, without giving it too much emphasis-Pache-Hébert et al., 2014; Godbout, 2017). Students may also get involved in various school committees: newspaper or radio, Amnesty International, etc. The International Day Against Homophobia also presents an opportunity to speak out, specifically when a member of the teaching staff is known for homophobia. School mobilizations may take the form of petitions, sit-ins, and more recently social media campaigns, such as the 2018 Carrés jaunes (yellow squares) movement protesting dress codes deemed sexist.

Thus, young students try to convince adults ruling their schools to do their share to save the planet, or to let them make some ecological improvements at school, long before considering strikes or resorting to civil disobedience and $\mathrm{DiO}$ politics. Indeed, students all around the world have been suggesting environmentally friendly ideas for years and setting up green committees in schools, organizing film projections and talks on waste sorting and producing natural wax food wrap, among other projects, or participating in the Youth Climate Action Conference in Australia in 2007 (Partridge, 2008; Corner et al., 2015; O'Brien et al., 2018; and United Nations, Youth in Action on Climate Change: Inspiration from Around the World, 2013; see also Fisher, 2016; Cocco-Klein and Mauger, 2018; Holmberg and Alvinius, 2020). In the province of Québec, from 2017 to 2019, there have been three editions of the Sommet jeunesse sur les changements climatiques (Youth Summit on Climate Changes), which brought together about 350 high school students (Le Soleil, May 18th, 2019).

Yet, youth who participated in this study highlighted different forms of adult instrumentalization or opposition to their plans to "green" their schools. This begins in primary school, where green committees organize "clean-up days" for all students, who have to come with garbage bags to pick up trash around the school. Under the appearance of $\mathrm{DiO}$ politics, it appears to be a greenwashing operation organized and coordinated by and for adults who thus get free-and more or less enthusiastic-labor to clean the grounds at no cost to the administration.

The interviews for this study also revealed that school administrations often use student council members to carry out tasks lending the appearance of sincere concern for the environment. The Collège Mont-Saint-Louis (Montréal) boasts in its 2018-2019 annual report (accessible online) that its student council-the Association générale des étudiants (AGE)organized an "electronics pick-up for environment week." However, a student from that school confided that "the problem with the AGE is its lack of power. It is to make us think that we have power, while we have none. Even teachers know it. It's mostly adults who handle everything."

The same control and opportunism seem to be at work with students who volunteer to sit on green committees. In a Montréal school where uniforms are mandatory, the green committee decided to organize a thrift sale for used uniforms to avoid waste. The school administration explained that the company selling uniforms would dispute the loss of revenues ${ }^{2}$. The same green committee proposed banning plastic bottles from the cafeteria, but the service provider threatened to increase prices to compensate for losses. "It's always a matter of money," expressed

${ }^{2} \mathrm{~A}$ similar project was started at another Montréal school, without any backlash from the company. 
the student describing these projects. He also denounced the fact that the same supervising teacher who established the committee held a member status, allowing him to reject student plans by saying that "the administration will not agree with this or that." Some students also protested against food waste in the cafeteria. In vain. A Secondary four delegate to the student council at a Montréal school explained that,

\footnotetext{
"the student council and board have a legal basis in the Education Act, but green committees don't. It's entirely up to the school administration and the teacher in charge. In my school, a teacher formed the green committee after climate strikes, and students on it were mostly volunteers, for example to recycle."
}

He also remarked that attempts to introduce recycling at schools ran into two problems: recycling is not included in the job description of janitors and recycling companies do not have formal permission to enter school grounds with their trucks. This serves as an excuse to have students work as volunteers. A school administration for instance agreed to install composting bins but asked students to pick them up, transport them, and wash them according to a schedule planned by a teacher.

The same power relations are reproduced in the Association des élèves du secondaire (Association of Secondary Students) (AESCSDM), founded by the Montréal School Board (CSDM). The AESCSDM is introduced on its official website as "a voice which speaks for them [the students] and represents them." Approximately, 40 students participated in an assembly gathering about once a month from December to the end of the school year. Three adults from the CSDM also participated. In 2019, a delegate proposed during an assembly that the AESCSDM calls for climate strikes at all CSDM schools. The adults interjected stating that more information was needed about the mobilization and that, most importantly, consideration should be taken to avoid tarnishing the CSDM image. According to a delegate, "these interventions nipped the idea in the bud. There wasn't even a vote on the proposal. Yet we don't represent the CSDM, we represent students from the CSDM! But they told us, 'You can't!'

In another Montréal school, a green committee, set up without adult participation, proposed gardening workshops and flower boxes to be installed in front of the school. In vain. In another school in Montréal, a student council delegate initiated a green committee in February 2019 without support from the administration, to relay calls to protest on Friday afternoons and offer alternative actions to students who could not or did not want to go on strike for fear of reprisal. In reaction, the administration decided to create its own green committee in the fall of 2019, with student council members and an adult to supervise them. The student who provided this information was outraged by this maneuver: "It's so immature! They are playing a game, but we aren't there to play. It's hard to work with immature people, who very often lie to us." The principal even handed out candies one Friday to discourage youth from striking.

In other schools, the administration simply refused to allow a green committee to form, sometimes out of concern of being associated with groups like Greenpeace. Students, therefore, continued to engage in political training and activism outside school. As such, one student participated in an ecology training camp, where she heard for the first time about indigenous struggles and direct democracy. She then drew the conclusion that school is "a kind of dictatorship."

\section{RESULTS: CLIMATE STRIKES}

Students have been organizing strikes since at least the second half of the nineteenth century, though very little scholarly research pertain to this phenomenon (Great Britain being an exception: Adams, 1991; Cunningham and Lavalette, 2016). At times, student strikes are part of national mobilizations-for example, against racial segregation in the United States in the 1960s, against South African apartheid in the 1970s and 1980s, against the dictatorship in Haiti in 1985, during the first Intifada in Palestine around 1990, against the political elite- "dinosaurs" —in Thailand in 2020 — and even of international mobilizations, such as those against both wars on Iraq in 1991 and 2003.

In Québec (Dupuis-Déri, 2020, 2021b), student strikes have been used to defend comrades expelled by the administration, protest anti-Semitic comments, oppose tuition increases, obtain a functional heating system, and establish anti-racist and antisexist codes. "Strikes" have sometimes been organized by parents keeping children at home as a form of protest, for example, to get adequate school transportation or to defend the French language. Most often, however, students are the ones initiating strikes, though strikers may be members of political organizations. During the 1930s economic crisis, for example, members of Young Pioneers, a socialist organization, were among the twentyseven 11-year olds striking at Aberdeen School in Montréal to demand free milk and clothing for children whose parents were unemployed. In 1947, the "chocolate bar strike" mobilized youth across Canada in April and May against post-war speculators jacking the price per bar from 5 to 8 to increase profits. Students protested and stormed newspaper offices, a radio station, the Winnipeg City Hall, and provincial parliaments in British Colombia and Manitoba (Fitzsimmons Frey, 2014).

Other movements affected the entire province of Québec. As such, high school students went on strike against an increase of the minimal passing grade of 50 to $60 \%$ at the beginning of the 1980s; in opposition to wars against Iraq in 1991 and again in 2003; and, in 1999, against the cancelation of extracurricular activities, a pressure tactic used by the union of teachers in its negotiations with the government. In the latter, the movement featured numerous bridge and highway blockades and the police arrested 270 youth in the Chomedey de Maisonneuve schoolyard in Montréal (Le Devoir, September 24, 1999).

This overview of student strikes and the social and political engagement of students at school does not directly explain the strong youth mobilization for climate in Québec. Plenty of other countries had similar student strikes in the past, and for climate. Nevertheless, recalling the history helps to nuance exceptionalism around climate mobilization, which in any case was preceded by numerous "green" actions in schools. 
In 2019 in Montréal, Sara Montpetit relayed Greta Thunberg's call for strikes every Friday afternoon. She had earlier been the Secondary two delegate to the student council at RobertGravel public school in Outremont (Montréal). She realized then that the council was somewhat ineffective and powerless. Therefore, she called for action through private social media, specifically Instagram, without the support of any institutional school committee. About 200 students responded to the call on the first Friday, including 100 at her own school. The administration put them in detention, during which they had to write an essay on individual political engagement. Similar repression did not discourage Friday strikers from pursuing their cause, but Sara Montpetit became overwhelmed by the volume of organizing tasks and thus put out a call on social media for a meeting in a café to get help.

Approximately 40 students from different schools responded to the invitation, dividing up tasks and responsibilities, ergo founding Pour le futur Montréal (For the future Montréal). Based on the suggestion of Sara Montpetit, students stood on tables in school cafeterias to harangue their peers and encourage them to join the Friday afternoon strike. In some schools, strikers stood on chairs in the lobby or paraded in the corridors chanting and banging on lockers to encourage other students to rally. Many strikers ceased attending the detention, with or without support from their parents.

Leading up to the first global day of action for climate on March 15, 2019, students from Robert-Gravel School got permission from the administration to hold a general assembly supervised by a teacher in the cafeteria. Such concessions are very rare in the history of high school strikes (though a few instances occurred during the "Printemps érable" in 2012). At Montcalm School in Sherbrooke, two girls launched a call on Facebook for the March 15th protest, without consulting their school administration. A member of the student council then convinced the administration to announce the call over the school intercom, in exchange for allowing adults to supervise the march.

In preparation for March 15th, several young people created placards and banners at home or at school, developing or adapting diverse slogans, "I came to tell you that you can change" " "There is no plan B"; "The school calls this unjustified absence but we are motivated to save our planet!" 5 . On the morning of March 15th, these young people jumped out of bed, particularly early to participate in picketing in front of their school and block its entrance. At Sophie-Barat public school, for example, the picket lines were spread out and the announcement of administration that classes would be canceled for the day was met with cries of joy. As we shall see, there was no consensus among students over blocking doors and picketing. Students chalked slogans onto the sidewalk in front of some schools. Contingents of strikers then converged on downtown areas to

\footnotetext{
${ }^{3}$ Often translated as "Maple spring" in French it is a pun on "Arab spring" (2011) and refers to the student strike that overtook Québec in 2012.

${ }^{4}$ In French, "Je suis venue te dire que tu peux changer." Lyrics from, "La fille de personne" (no one's daughter) by Hubert Lenoir.

${ }^{5}$ Literal translation of a play on words, "L'école appelle ça une absence non motivée mais nous sommes motivées à sauver notre planète!".
}

participate in the march. At Magdeleine Public School in La Prairie, on the south shore of Montréal, however, the protest took place at noon on a boulevard. At Academie Lafontaine, a private school on the north-shore of Montréal, the administration organized a human chain around the building. In both cases, no class was canceled.

Situations can thus vary considerably, depending on the educational institution, where power relations arise from an unequal triangulation between students on one hand and two groups of adults, school administrations, and parents on the other hand. Indeed, some administrations communicated with parents to encourage them to discipline their children. At PaulGérin-Lajoie-d'Outremont public school, the principal wrote to parents in the lead up to the March 22nd protest, explaining that he had been tolerant up to that point, but that "the Basic School Regulation set out a school calendar in which at least 180 days must be devoted to educational services. In this sense, the code of conduct and other measures thought to be necessary will be applied in case of non-compliance. [...] We are counting on your collaboration in encouraging your child's attendance at school." The principal, who specified that he could "ask for a police presence" nevertheless ended his letter on a diplomatic note, calling the "climate and environmental protection cause" just and important and stating that he was open to "organizing a committee to carry out concrete actions for our school and our neighborhood." On March 29th, the principal wrote another letter to parents rejoicing that students had "decided to clean the area around the school," but decrying the fact that "around one hundred students from the school had blocked the entrance [...] Our socio-community officer as well as police colleagues [sic] had to be called" in case "the situation degenerated." The principal then promised to invite the MP of the riding to meet the students so that "their voices" could be heard.

Power relations shifted throughout 2019. For example, many school administrations were tolerant of the first Friday afternoon strikes but later clamped down on the movement, which did not seem as if it was going to subside. The detention periods were granted and exams scheduled for Friday afternoons, which penalized strikers using academic performance evaluations. Teachers more sympathetic to the movement projected movies instead to avoid penalizing strikers.

At the start of the 2019 fall term, CSDM declared September 27th to be a "pedagogical day," thus unburdening school administrations from the necessity of ensuring that 140,000 students attend class. A student involved in Pour le Futur Montréal called this decision "greenwashing." During the previous winter, she had participated in unsuccessful negotiations to convince the CSDM to allow students to go on strike. This shift on the part of the CSDM in the fall resulted in tension between the government, the Board, and the unions of teachers. As such, the Pointe-de-l'Île School Board (CSPI) decided not to follow suit, on the pretext of "responsibility to ensure the safety of its students on this day, which is officially a school day" [Métro (Montréal), September 19, 2019; La Presse, September 17, 2019; La Presse, September 18, 2019].

Students can thus sometimes benefit from significant institutional support during the mobilization, or, on the contrary, 
run into inflexible adults betraying democratic ideals. For instance, two students were suspended by the administration of Des Monts comprehensive school, in Sainte-Agathe-des-Monts in the Laurentians. "For people who asked for democracy, it's pretty extreme," one of the punished students told the media. In meetings with the school administration, with participation by the school security, the students had asked in vain for a strike assembly. Then they organized the assembly autonomously. The administration explained that students should have gone to the student council and that an assembly vote was invalid "because students are under 18" (they are nevertheless permitted to elect student council members). This independent assembly also voted to create a student organization separate from the school administration (Carabon, 2020).

\section{RESULTS: CLEAVAGES AND CONFLICTS BETWEEN STUDENTS}

As we can see, the political process leading to climate strikes and protests has been lengthier and more complex than media coverage would indicate. Moreover, the youth climate activism has had its fair share of conflict and interpersonal and collective divisions that do not receive media coverage, leading to present youth mobilization as mass, pretty festive, and homogenous. As a student from Sherbrooke said, "It's really divided, everyone has an opinion about the environment" and "lots of people want to look good, but don't change their behavior." One boy explained it this way, "I am not environmental, I don't believe in climate change, but I want to [go on strike] to play video games." Many students provide various justifications for opposing the protests, for example, the importance of not missing exams or because "it's wrong to protest," as one student said about the September 27, 2019 march. These varying positions result in friendship disappointments and stigmatization of ecologist students. "There are people I can no longer talk to," one student told me. Another said he was subject to provocation: "my friends teased me, they deliberately threw things that could be recycled or composted into the garbage in front of me and watched me pick them up and take them to recycling or compost bins." Participants to my research also pointed out that it is generally not only challenging for younger Secondary one and two students to stand on their grounds against both the administration and their parents but also hard for them to interact on an equal footing with Secondary four and five students, who tend to initiate and lead mobilizations.

A student as a public school in Montréal differentiated three tendencies among students in relation to climate: (1) "those who don't care," because "there are lots of climate skeptics"; (2) "those who protest, but don't know what they are talking about because they consume products from multinationals made by children"; and (3) students "who go to every protest" and hold relevant information and demonstrate real coherence, for example, by buying only second-hand clothing. The tensions between these positions may result in insults on social media or in person. As one student recounted,
"I was subject to insults. Because I was against the picket line [during the strike], they said that I was a hypocrite and I didn't really want to do anything for the environment. But these Secondary 5 folks just want an excuse to miss school, they buy and wear brand clothing while all my clothes are second-hand and I try to be vegetarian. We are organizing for the right reasons but we lose credibility with pickets. We discuss a lot with the administration, we do everything to get the administration really on our side $[\ldots]$ we want there to be composting, recycling. [...] We organize 'Wednesday pick ups' on the grounds with gloves and bags, we pile it up and show the bags to the whole school, to prove that you have to 'act concretely' and to show them everything that is thrown on the grounds."

The ideological divisions among students reflect different ways of conceiving DiO politics, more or less autonomous and conflictual toward adults and institutions and debate over the best ways to struggle for the climate and the environment. Here, we seem to come back to the traditional dichotomy between a reformist and institutional environmentalism and a radical and autonomous ecologism (Gandon, 2009; Combes, 2010; Dufoing, 2012; Larrère, 2012, p. 110). We can also see an opposition playing out between the forms of mobilization identified by Adams (1991) in his study on strike of pupils in the United Kingdom: alliance (with teachers, parents, and media) or confrontation (strikes, pickets, sit-in, etc.).

School administrations may manipulate these divisions between students to obstruct the strike movement. The PèreMarquette school administration, for example, had a real communication strategy to discourage students from striking and channel them toward institutionalization. In April 2019, the president of the Board of the school and the principal jointly signed a letter to parents and students, to "inform them of concrete actions." For example, "the student council was met with and has prepared itself to examine the best way to consult the student body about changes [...] toward reducing the ecological footprint of the 1,350 students." The letter also announced that a group of Secondary five studentsseven girls-had proposed installing compost and recycling bins, replacing paper plates with ceramic plates in the cafeteria, and encouraging students to bring their own utensils to avoid throwing out plastic utensils in the cafeteria. The letter proudly highlighted the establishment of a team "to clean up around the school," including a large neighboring park, and a second one, a "Protect our Future" student team, to raise awareness with fellow students about environmental issues. It also raised the possibility of opening an "eco-shop." On the surface, this looks like DiO politics, but in reality, the actions were authorized, supervised, and instrumentalized by the school administration. This letter was accompanied by another message from the principal, this time addressed only to parents. It explained that he had spoken to "several politically involved and activist students" who "participate in the marches" but who did not encourage other students to "limit access to education," that is, block the school and go on strike. The principal finally emphasized that "the administration, the school-team, representatives of the board and a majority of pro-environmental students want, both for academic success and environmental reasons, classes to take place normally" (our italics). It is impossible to know how the 
administration was able to assess what the "majority of proenvironmental students" wanted.

That said, the same individual can be seen as too moderate in one situation and too radical in another. One student, for example, got a poor reception from the green committee by the "little clique of insiders" who thought her proposals were too "radical" because she suggested supporting the strike and starting a poster campaign in the school. At the same time, she herself ended a friendship with a comrade she saw as too radical and "angry" at the administration, and she was afraid that his idea of locking the doors on the day of the strike would lead to their getting kicked out of school.

Another Secondary three student also found herself placed at times on the side of moderation and respect for the school, and at others on the side of the unruly protest. The administration at her school had refused to organize a general assembly about the climate strike on March 15 2019. Reacting to an announcement by the administration over the intercom that there would be classes the following day, March 15th, she got on a table in the cafeteria and shouted, "The earth is a time bomb, it's our future!" and announced the strike and march the following day. The student was immediately sent to the administration, who suspended her for 3 days for "insubordination" and demanded that she be accompanied by her parents when she came back. After the winter 2019 protests, the same student negotiated with the administration and got composting, recyclable utensils, a clean-up day in the recreation area outside, and the formation of a green committee, supervised by a teacher who had set up a "green brigade," which went to the cafeteria and classes to raise awareness and organize talks. Things thus seemed to be moving in a positive direction for this student, who entered Secondary four in fall 2019 and again submitted a request to the administration to organize a strike assembly for the September 27th global protest. The school administration told her that secondary students had "no right" to hold such assemblies and suggested instead that she run for student council, so that "I wouldn't get back onto the table."

\section{RESULTS: AUTONOMOUS ACTIONS AND LEGITIMACY OF CIVIL DISOBEDIENCE}

In part because of the institutional limits the strikers encountered in their schools, youth adopting a more conflictual posture joined local committees of Extinction Rebellion (XR) Youth, an organization, which practices civil disobedience, often risking arrest (Axon, 2019). Youth, who took part in this study, had participated in several of these actions, including an action on April 17, 2019 outside Montréal office of Québec Prime Minister François Legault. Thirty ecologists took part, with adults, including an 82-year-old activist, helping out. Some activists chained themselves to the building, others painted its windows and blocked Sherbrooke Street before starting to march (La Presse, April 17, 2019). A few days later, Extinction Rebellion protested, pouring fake blood outside a Montréal hotel, where the Nature Champions Summit was being hosted by the Federal Ministry of the Environment (Radio-Canada, April 25, 2019).
On May 27th, some activists disrupted the general assembly of the Québec Oil and Gas Association, whereas others glued the palms of their hands to the doors of the hotel where the event was taking place (Journal de Montréal, May 27, 2019). On October 12th, Montréal police arrested about 40 ecologists who had blocked Sherbrooke Street (La Presse, October 12, 2019). On November 29th, dozens of activists protested in shopping centers to denounce overconsumption, including in Sherbrooke. Some activists unfurled banners in shopping centers, blocked entrances to shops, and glued their hands to windows. The police made several arrests (Journal de Montréal, November 29, 2019).

Here, we see a form of $\mathrm{DiO}$ politics. Even within a rather radical network such as Extinction Rebellion, however, there may be a myriad of interpersonal and collective divisions. In Montréal, the first meetings of the youth section brought together around 40 young people in the offices of Greenpeace to discuss, "lots of things, everything, it was really nice. There were proposals for actions, we discussed who was willing to be arrested, etc." However, the girl and boy who started the group were a couple and their conflictual separation set off maneuvering over alliances in the collective, despite a mediation committee composed of four girls. "Don't start a group as a couple," one of the respondents concluded. This split not only followed logics of friendship and enmity but was also a conflict between "moderates" and the "extreme left," as one of the study participants characterized the camps.

While the "moderates" wanted to speak strictly about the environment and included pro-independence Québec nationalists, the "extreme leftists" wanted to broaden the analysis to issues, such as racism, particularly in relation to First Nations indigenous people. Moreover, arrests-even willingly riskedincreased the anger that many of them felt toward the police. This is also a driving force behind the political action of other Québec youth, particularly in "youth centers," where people identify with the Collectif opposé à la brutalité policière (Collective Opposed to Police Brutality) (COBP) (Greissler et al., 2020, p. 145-149). Others believed that the struggle against the police did not line up with the environmental cause. The situation deteriorated over the weeks, with a flood of sometimes virulent cyber-messages, and several very intense meetings marked by tears and shouting. This conflict led to the departure of members of the moderate camp ${ }^{6}$.

Even though the situation may be tense and conflictual among young ecologists, there are still points of convergence and connections between more moderate and more radical tendencies. One Montréal student, for example, volunteered to take part in a collective action risking arrest, even though he had no civil disobedience training, in order to actually assess the relevance of this tactic for CEVES. CEVES was launched in February 2020 as a partnership between Pour un futur Montréal (PLF), Devoir environnement collectif (Collective

\footnotetext{
${ }^{6}$ There are necessarily contradictory perspectives in this kind of conflict and thus other ways of describing the situation than the one offered here; moreover, the situation undoubtedly evolved after this study was completed, just before the COVID-19 pandemic started, in the winter of 2020. Here, the author simply wanted to make the point that groups like Extinction Rebellion are also affected by divisions, which influence their composition and political choices.
} 
Environmental Duty, but "devoir" also means homework) (DEC), and La Planète s'invite à l'Université (The Planet Goes to University) (LPSU) with the mandate of organizing a week of strikes (later canceled because of COVID-19). This provincewide organization brought together both secondary and postsecondary youth under a primary principle of respect for "the science and indigenous knowledge" of First Nations. It offered training workshops in high schools through green committees. During workshops, students were encouraged to brainstorm possible actions in their schools, seen as sites of "transition." Promoting diversity in public speaking, CEVES had university (Christina Lau, McGill University), CEGEP (Tristan Pérez), and high school (Mika Pluviose) spokespeople, the latter being also a member of Extinction Rebellion who signed with other young and racialized spokespeople an open letter denouncing the "mainstream environmental movement" for its lack of diversity and representativity, tokenism, systematic discrimination, and oppressive practices (Zadigue-Dubé et al., 2020).

\section{DISCUSSION}

It might be argued that such $\mathrm{DiO}$ politics and autonomous direct actions are legitimate according to the political philosophy. Although civil disobedient youth is said to be "represented" by student councils, there is always at least one adult sitting on any committee of students and maintaining control of decisionmaking processes, even if student members are elected or not. Therefore, these students and their associations are not politically free (sovereign), since they are kept under what one may call the "political domination" of adults. Moreover, students have generally no say in school rules, codes of conduct, and punishments, and no way of challenging the interpretation and application of said rules established by adults (Adams, 1991; Raby and Domitrek, 2007; Raby, 2008; Caron, 2014; Demers et al., 2018). Finally, attempts made by adults and some students to moderate and neutralize other students may lead to serious consideration and acceptance of autonomous direct action and civil disobedience as a last resort.

While evaluating the legitimacy of civil disobedience, one may draw upon Alan Carter's "defense of radical disobedience" (Carter, 1998), developed from an ecological perspective in opposition to far more moderate theories of philosophers such as John Rawls and Ronald Dworkin [he also could have included Jürgen Habermas]. His inspiration came from the 1990s when sabotage actions by the Animal Liberation Front, Earth First! and the Earth Liberation Front caused damages estimated at hundreds of millions of dollars. It was also a time when British ecologists mobilized against the development of the M11 highway by occupying building rooftops and trees and Reclaim the Streets organized anti-capitalist street parties in the financial district of London.

According to Alan Carter, we should not only consider the political regime, will of the majority, and fundamental rights of individuals and minorities but also the interests and well-being of unborn future generations who cannot take part in present decisions, to accede or oppose to them. "The date of birth of the victim is morally insignificant," reinforces Carter (1998, p. 38), who believes in the moral and political responsibility to act against an immediate ecological catastrophe that will also kill people in the future. In such a situation, we cannot remain inactive under the pretense that only governments have the responsibility to act or that freedom of expression allows us to express our concerns in the media. We must both change our own behavior and act collectively to convince or force the majority and the government to do so as well. He concludes that political forces (governments, parties, etc.) and economic forces (private companies and the wealthy) must be targeted by radical disobedience to prevent ecological catastrophe, but he should also have included school administrations as legitimate targets for ecological activists. Although Carter considered individual adults currently living and future generations, his thinking clearly aligns with the youth climate movement. The latter addresses most adults holding political and economic power not only in the name of generations to come, including children of present-day children but also their own generation, that are expected to suffer adverse effects of the climate crisis once becoming adults.

For young people involved, it is undoubtedly a very intense, existential, and political experience, as this Secondary three student from a Montréal school testifies:

"It is so powerful to be together with everyone; it gives a feeling
of being able to do anything, especially all these people of my age,
minors, with the same ideas, the same political goal: 'OK, we will
face the consequences of missing school, but it isn't a problem
because this is more important.' It's really beautiful, there's real
power, it gives us hope, our generation is our best hope. We are
the ones who are going to be left with this problem. I think of my
little cousins who were just born, of my future children. How is it
that it is us, children who don't even have the right to drive a car
or vote, who have the responsibility to save the human species?"

\section{CONCLUSION}

While it is always risky to make predictions, we can assume that this cohort of strongly mobilized high school students will, in a few years, join the post-secondary student movement and reenergize it. Indeed, the Québec post-secondary student movement is known to be one of the most dynamic and contentious in North America, which partially explains the lower tuition fees in this province (Ancelovici and Guzmán-Concha, 2019). Yet, the movement has been more or less in abeyance due to the relative failure of "national" strikes for free education and against hydrocarbon in 2015 and for paid traineeships in 2019.

One of the participants in this study, who had reached the age of majority and participated in CEVES, remarked that,

"high school youth are starting to have organized bases that are
quite a bit stronger than we had, they will benefit from allies in
the struggle, like Greenpeace and La planète s'invite à l'Université,
that's why it works, but also because the issue is clearly more
pressing and this crisis will directly affect them more and more,
much more than a potential increase in tuition. They are ready to
take more risks. They are also very well informed, they present
and discuss concepts, they participate in discussions during
CEVES training camps, even though we remain concerned with
university students imposing their ideas on high school students." 
The issue is in fact of unequaled importance, as a student at the international school Du Phare, in Sherbrooke, said in September 2019, "Like grown-ups now, we have an obligation to take responsibility for the 6th extinction, take responsibility for our self-destruction. Because multinationals subjugate democratic regimes through lobbying, in which neither the environment nor citizens are variables" (Lessard, 2019). It has been more than 65 years since this catastrophe was announced. Indeed, ecologists who could be grandparents or even great-grandparents of the current youth generation already sounded the alarm in the 1960s. For example, ecologist Murray Bookchin, born in 1921, wrote an article in the journal Anarchy in 1965 that was entitled "Ecology and revolutionary thought," in which one can read:

As an example of the scope of modern man's disruptive role, it has been estimated that the burning of fossil fuels (coal and oil) adds 600 million tons of carbon dioxide to the air annually ... aside from an incalculable quantity of toxicants. Since the Industrial Revolution, the overall atmospheric mass of carbon dioxide has increased by 25 percent over earlier, more stable, levels. It can be argued on very sound theoretical grounds that this growing blanket of carbon dioxide, by intercepting heat radiated from the earth, will lead to more destructive storm patterns and eventually to melting of the polar icecaps, rising sea levels, and the inundation of vast land areas. Far removed as such a deluge maybe, the changing proportion of carbon dioxide to other atmospheric gases is a warning about the impact man is having on the balance of nature.

Since then, a youth generation has emerged that understands the urgency to act, en masse. For many strikers today, the climate strike should not only be general but also permanent because it is a matter of their very survival.

\section{DATA AVAILABILITY STATEMENT}

Requests to access the datasets should be directed to Francis Dupuis-Déri, dupuis-deri.francis@uqam.ca.

\section{REFERENCES}

Adams, R. (1991). Protests By Pupils: Empowerment, Schooling and the State. Bristol: The Falmer Press.

Ancelovici, M. (2017). Christian Rioux : portrait du chroniqueur en idéologue. Ricochet. 18 January.

Ancelovici, M., and Dupuis-Déri, F. (eds.) (2014). Un printemps rouge et noir : regards croisés sur la grève étudiante de 2012. Montréal: Écosociété.

Ancelovici, M., and Guzmán-Concha, C. (2019). Struggling for education: the dynamics of student protests in Chile and Quebec. Curr. Sociol. 67, 978-996. doi: $10.1177 / 0011392119865763$

Arendt, H. (1972). Crises of the Republic: Lying in Politics, Civil Disobedience, on Violence, Thoughts on Politics and Revolution. New York, NY: Harvest Book.

Axon, S. (2019). Warning: extinction ahead! Environ. Space Place 11, 1-26. doi: 10.5749/envispacplac.11.2.0001

Bergmann, Z., and Ossewaarde, R. (2020). Youth climate activists meet environmental governance: ageist depictions of the FFF movement and Greta Thunberg in German newspaper coverage. J. Multicultural Discourses 15, 267-290. doi: 10.1080/17447143.2020.174 5211

\section{ETHICS STATEMENT}

The studies involving human participants were reviewed and approved by Comité institutionnel d'éthique de la recherche avec des êtres humains de l'UQAM [CIEREH@UQAM.CA]. Written informed consent to participate in this study was provided by the participants' legal guardian/next of kin.

\section{AUTHOR'S NOTE}

This article will resituate the Québec-based mobilizations of the 'Youth strike for climate' within the little-known tradition of student strikes and the history of "green" actions in schools. This will allow institutional blockages to be identified before examining divisions among strikers and then addressing the issue of legitimacy of radical civil disobedience. Two research assistants worked (media web sites) on this project: Mélissa Castilloux, MA candidate, and Héloise Michaud, Ph.D. candidate (political science, Université du Québec à Montréal-UQAM).

\section{AUTHOR CONTRIBUTIONS}

The author confirms being the sole contributor of this work and has approved it for publication.

\section{FUNDING}

The author research project Démocratie et contestation dans les écoles secondaires au Québec (Democracy and protest in high schools in Québec) is supported by funding from the Social Sciences and Humanities Research Council of Canada.

\section{ACKNOWLEDGMENTS}

The text has been translated from the French by Mary Foster, and revised Catherine Déri.

Bock-Côté, M. (2019a, June 8). Greta thunberg, la prophétesse ? Le J. Montréal. Available online at: https://www.journaldemontreal.com/2019/06/08/gretathunberg-la-prophetesse

Bock-Côté, M. (2019b, July 31). Greta sur son voilier. Le J. Montréal. Available online at: https://www.journaldemontreal.com/2019/07/31/gretasur-son-voilier

Carabon, F. (2020, March 4). Climat : deux élèves du secondaire suspendus pour avoir organisé un vote de grève. Métro. Available online at: https://journalmetro.com/actualites/national/2425330/climat-deux-elevessuspendus-vote-greve-ecole-secondaire/

Caron, C. (2014). Vues, mais non entendues: les adolescentes québécoises et l'hypersexualisation. Québec: Presses de l'Université Laval.

Caron, C. (2018). La citoyenneté des adolescents du $21^{\mathrm{e}}$ siècle dans une perspective de justice sociale: pourquoi et comment? Lien Soc. Politiques. 80, 52-68. doi: $10.7202 / 1044109$ ar

Carter, A. (1998). In defence of radical disobedience. J. Appl. Philos. 15, 29-47. doi: 10.1111/1468-5930. 00071

Cervera-Marzal, M. (2013). Désobéir en démocratie : la pensée désobéissante de Thoreau à Martin Luther King. Paris: Forges de Vulcain. 
Cocco-Klein, S., and Mauger, B. (2018). Children's leadership on Climate change: What can we learn from child-led initiatives in the U.S. and the Pacific islands? Children Youth Environ. 28, 90-103. doi: 10.7721/chilyoutenvi.28.1.0090

Combes, M. (2010). Réflexions sur le "capitalisme vert". Mouvements 63, 99-110. doi: $10.3917 /$ mouv.063.0099

Corner, A. O., Roberts, S., Chiari, S., Völler, S., Mayrhuber, E. S., Mandl, S., et al. (2015). How do young people engage with climate change? The role of knowledge, values, message framing, and trusted communicators. WIREs Climate Change 6, 523-534. doi: 10.1002/wcc.353

Cunningham, S., and Lavalette, M. (2016). Schools Out! The Hidden History of Britain's School Student Strikes. London: Bookmarks.

Demers, S., Clermont, A., Lefrançois, D., Éthier, M.-A., and Potvin, M. (2018). Quel rapport au droit les codes de conduite d'écoles secondaires impliquent-ils pour les jeunes? Revue Éduc. Soc. 42, 101-118. doi: 10.3917/es.042.0101

Dufoing, F. (2012). L'Écologie Radicale. Gollion: Infolio.

Dupuis-Déri, F. (2006). Les élections de conseils d'élèves: méthode d'endoctrinement au libéralisme politique. Revue Sci. Éduc. 32, 691-709. doi: $10.7202 / 016282 \mathrm{ar}$

Dupuis-Déri, F. (2007). Global protesters versus global elites: are direct action and deliberative politics compatible? New Political Sci. 29, 167-186. doi: $10.1080 / 07393140701431847$

Dupuis-Déri, F. (2020). "L'école contre la démocratie : les grèves d'élèves au secondaire," in Pratiques et corruptions de la démocratie moderne, ed J. BouladAyoub (Québec: Presses de l'Université Laval), 113-129.

Dupuis-Déri, F. (2021a). Mobilisations de la jeunesse pour le climat au Québec : Analyse des dynamiques conflictuelles à l'école. Sociologie et Sociétés. Forthcoming.

Dupuis-Déri, F. (2021b). Histoire des grèves d'élèves du secondaire au Québec : démocratie et conflictualité. Revue des sciences de l'éducation. Forthcoming.

Dworkin, R. (ed.). (1985). "Civil disobedience and nuclear protest," in A Matter of Principle (Cambridge, MA: Harvard University Press), 104-116.

Fisher, S. R. (2016). Life trajectories of youth committing to climate activism. Environ. Educ. Res. 22, 229-247. doi: 10.1080/13504622.2015.1007337

Fitzsimmons Frey, H. (2014). "Canadian chocolate war: imagining, depicting, and fearing "yougster" power," in Nationalism and Youth in Theatre and Performance, eds V. Pettersen Lantz, A. Sweigart-Gallagher. New York, NY; London: Routledge.

Fuji Johnson, G. (2012). And, I mean every word of it': Comments on Francis Dupuis-Déri's "Global protesters versus global elite: Are direct action and deliberative politics compatible?". Ethics Forum. 7, 103-111.

Gallant, N. (2018). “The 'good', the 'bad' and the 'useless': young people's political action repertoires in Quebec," Young People Re-Generating Politics in Times of Crises, ed S. Pickard, J. Bessant, (London: Palgrave Macmillan), 77-94. doi: 10.1007/978-3-319-58250-4_5

Gandon, A.-L. (2009). L'écoféminisme: une pensée féministe de la nature et de la société. Recherches Féministes 22, 5-25. doi: 10.7202/037793ar

Garneau, S. (2016). "Pour changer le regard sur les jeunes et le politique : quelques idées de recherche," Les Jeunes et l'action Politique : Participation, Contestation, Résistance. (Québec: Presses de l'Université Laval), 233-257.

Gauthier, M. (2003). The inadequacy of concepts: the rise of youth interest in civic participation in Quebec. J. Youth Stud. 6, 265-276. doi: $10.1080 / 1367626032000138255$

Godbout, A. (2017). Pour une démocratie engagée : Vox Populi et l'éducation à la citoyenneté dans les écoles du Québec. Québec: Fondation Jean-CharlesBonenfant and Assemblée nationale du Québec.

Greissler, É., Lacroix, I., and Morissette, I. (2020). Penser l'engagement des jeunes «en difficulté 》: Leurs expériences à partir des milieux de vie. Québec: Presses de l'Université du Québec.

Holmberg, A., and Alvinius, A. (2020). Children's protest in relation to the climate emergency: a qualitative study on a new form of resistance promoting political and social change. Childhood 27, 78-92. doi: 10.1177/09075682 19879970

Lacroix, I. (2016). La participation collective des jeunes en protection de l'enfance: une revue de la littérature internationale, Chaire de recherche du Canada sur l'évaluation des actions publiques à l'égard des jeunes et des populations vulnérables/École nationale d'administration publique (ENAP).

Larrère, C. (2012). L'écoféminisme : féminisme écologique ou écologie féministe. Tracés 22, 105-121. doi: 10.4000/traces.5454
Le Glaunec, J.-P. (2020). Une Arme Blanche: La mort de George Floyd et les Usages de l'histoire dans le Discours Néoconservateur. Montréal: Lux.

Lessard, A. (2019). Mobilisation monstre dans les rues de Sherbrooke. Available online at: EstriePlus.com (accessed September 27, 2019).

Milner, H. (2005). The phenomenon of political dropouts: Canada in comparative perspective. Montréal, QC: Institut de recherche en politiques publiques.

O'Brien, K., Selboe, E., and Hayward, B. M. (2018). Exploring youth activism on climate change: dutiful, disruptive, and dangerous dissent. Ecol. Soc. 23:42. doi: 10.5751/ES-10287-230342

Pache-Hébert, C., Jutras, F., and Guay, J.-H. (2014). Le comité des élèves dans les écoles primaires et secondaires: une recension des écrits. Revue Canadienne L'Éduc. 37, 1-27. Available online at: https://journals.sfu.ca/cje/index.php/cjerce/article/view/1723

Partridge, E. (2008). From ambivalence to activism: young people's environmental views and actions. Youth Stud. Australia 27, 18-25.

Pickard, S. (2019). Young environmental activists are doing it themselves. Political Insight 10, 4-7. doi: 10.1177/2041905819891364

Quéniart, A., and Jacques, J. (2004). Apolitiques, Les Jeunes Femmes? Montréal: Remue-ménage.

Raby, R. (2008). Frustrated, resigned, outspoken: students' engagement with school rules and some implications for participatory citizenship. Int. J. Children's Rights 16(1), 77-98. doi: 10.1163/092755608X267148

Raby, R., and Domitrek, J. (2007). Slippery as fish... but already caught? Secondary students' engagement with school rules. Can. J. Educ. 30, 931-958. doi: $10.2307 / 20466669$

Rawls, J. (1999). Theory of Justice. Cambridge, MA: Belknap Press of Harvard University Press.

Reginensi, L. (2005). Annick Percheron et l'univers politique des enfants. Revue d'Histoire Sci. Humaines 12, 173-192. doi: 10.3917/rhsh.012.0173

Rioux, C. (2019a). Sainte greta. Le Devoir. 19.

Rioux, C. (2019b). Réponse de Christian Rioux. Le Devoir. 24.

Shields, A. (2019). La question d'un examen sur le climat soulève l'ire des élèves. Le Devoir.

Simon, A. (2020). Are children interviewees just like any others? Bull. Méthodol. Sociol. 146, 81-98. doi: 10.1177/0759106320908223

Surprenant, M.-E., and Bigaouette, M. (eds.) (2013). Les Femmes Changent la Lutte: Au Cour du Printemps Québécois. Montréal: Remue-ménage.

Theurillat-Cloutier, A. (2017). Printemps de Force: Une Histoire Engagée du Mouvement Étudiant au Québec (1958-2013). Montréal: Lux.

Wall, J. (2011). Can democracy represent children? Toward a politics of difference. Childhood 19, 86-100. doi: 10.1177/0907568211406756

Walzer, M. (1970). "Civil disobedience and corporate authority," in Obligations: Essays on Disobedience, War and Citizenship, ed M. Walzer, (Cambridge, MA: Harvard University Press), 24-45.

Weiss, J. (2020). What is youth political participation? Literature review on youth, political participation and political attitudes. Front. Political Sci. 2, 1-13. doi: 10.3389 /fpos.2020.00001

Westheimer, J., and Kahne, J. (2004). What kind of citizen? The politics of educating for democracy. Am. Educ. Res. J. 41, 237-269. doi: 10.3102/00028312041002237

Zadigue-Dubé, É., Pluviose, M., Zhang, S. T., and Chiu, T. (2020). Lettre ouverte: discrimination systémique au sein du mouvement environnemental mainstream. J. Alt. (web). Available online at: https://journal.alternatives. ca/Lettre-ouverte-discrimination-systemique-au-sein-du-mouvementenvironnemental

Zinn, H. (ed.). (1968). "Second fallacy: the person who commits civil disobedience must accept his punishment as right," in Disobedience and Democracy: Nine Fallacies on Law and Order (Boston: South End Press).

Conflict of Interest: The author declares that the research was conducted in the absence of any commercial or financial relationships that could be construed as a potential conflict of interest.

Copyright (c) 2021 Dupuis-Déri. This is an open-access article distributed under the terms of the Creative Commons Attribution License (CC BY). The use, distribution or reproduction in other forums is permitted, provided the original author(s) and the copyright owner(s) are credited and that the original publication in this journal is cited, in accordance with accepted academic practice. No use, distribution or reproduction is permitted which does not comply with these terms. 